\title{
Abnormal Cell Surface Antigen Expression in Individuals with Variant CD45 Splicing and Histiocytosis
}

\author{
SALLY BOXALL, JAMES MCCORMICK, PETER BEVERLEY, STEPHAN STROBEL, \\ PAOLA DE FILIPPI, RITU DAWES, CATHERINE KLERSY, RITA CLEMENTI, \\ EMANUELLA DE JULI, ALINE FERSTER, DIANA WALLACE, MAURIZIO ARICÒ, \\ CEZARE DANESINO, AND ELMA TCHILIAN
}

\begin{abstract}
The Edward Jenner Institute for Vaccine Research, Compton, Berks RG20 7NN, U.K. [S.B., J.M., P.B., R.D., D.W, E.T.], Immunobiology Unit, Institute for Child Health and Great Ormond Street Hospital NHS Trust, London WC1N 1EH, U.K. [S.S.], Genetica Medica, Università di Pavia and I.R.C.C.S. Ospedale San Matteo, Pavia 27100, Italy [P.F., R.C., C.D.], Servizio di Biometria ed Epidemiologia Clinica Direzione Scientifica - IRCCS Ospedale San Matteo, Pavia 27100, Italy [C.K.], Pneumologia, Ospedale Niguarda, Milano 20133, Italy [E.J.], Hemato-Oncologie, Hopital Universitaire des Enfants Reine Fabiola, Bruxelles 15-1020 Belgium [A.F.], Onco Ematologia Pediatrica, Ospedale dei Bambini, Palermo 90100, Italy [M.A.]
\end{abstract}

\begin{abstract}
ABST
Hemophagocytic lymphohistiocytosis (HLH) and Langerhans
cell histiocytosis (LCH) are members of a group of rare heter-
ogenous disorders, the histiocytoses, characterized by uncon-
trolled accumulation of pleomorphic infiltrates of leukocytes.
The etiology of these diseases is mainly unknown. CD45 is a
hemopoietic cell specific tyrosine phosphatase essential for an-
tigen receptor mediated signaling in lymphocytes and different
patterns of CD45 splicing are associated with distinct functions.
Recently a polymorphism (C77G) in exon 4 of CD45 causing
abnormal CD45 splicing and a point mutation affecting CD45
dimerization were implicated in multiple sclerosis in humans and
lymphoproliferation and autoimmunity in mice respectively.
Here we show that two patients with HLH exhibited abnormal
CD45 splicing caused by the C77G variant allele, while a further
\end{abstract}
The leukocyte common antigen CD45 is an abundant tyrosine phosphatase, essential for lymphocyte antigen receptor signal transduction (1). Both CD45 knockout mice $(2,3)$ and humans lacking CD45 expression $(4,5)$ are severely immunodeficient with very few peripheral $\mathrm{T}$ lymphocytes and impaired $\mathrm{T}$ and $\mathrm{B}$ cell responses.

Multiple CD45 isoforms can be generated by alternative splicing of exons $\mathrm{A}, \mathrm{B}$, and $\mathrm{C}$ of the extracellular domain $(6,7)$. In humans naïve $\mathrm{T}$ cells express high molecular weight CD45

Received May 2, 2003; accepted August 19, 2003

Correspondence: Elma Tchilian, M.D., The Edward Jenner Institute for Vaccine Research, Compton, Berkshire RG20 7NN, U.K.; e-mail: elma.tchilian@jenner.ac.uk

Supported by Telethon grants E755 and C30, IRCCS Policlinico San Matteo, ricerca corrente 80291 and 'Fondazione Pinzino' (M.A. and C.D.).

DOI: 10.1203/01.PDR.0000106803.15344.72
$21 \mathrm{HLH}$ patients have normal CD45. We have also examined 62 $\mathrm{LCH}$ patients and found three to have the $\mathrm{C} 77 \mathrm{G}$ mutation. Peripheral blood thymus-derived (T) $\mathrm{CD}^{+}$cells from normal individuals carrying the $\mathrm{C} 77 \mathrm{G}$ mutation show a significant decrease in the proportion of cells expressing L-selectin and increased frequency of cells with LFA- $1^{\text {hi }}$ expression. It remains to be established whether $\mathrm{C} 77 \mathrm{G}$ is a contributing factor in these histiocytic disorders. (Pediatr Res 55: 478-484, 2004)
Abbreviations
LCH, Langerhans cell histiocytosis
HLH, hemophagocytic lymphohistiocytosis
PBMC, peripheral blood mononuclear cells
PHA, phytohemagglutinin

isoforms, recognized by CD45RA MAb ("CD45RA" cells), but activation of the cells results in a change to expression of low molecular weight isoforms, detected by a CD45R0 MAb ("CD45R0" or memory cells) (8). Paragraph deleted. Several polymorphisms of the gene encoding CD45 (PTPRC at 1q3132) have been described and several of these cause altered splicing (9-14).

The C77G polymorphism (9-12) has been linked to the development of multiple sclerosis in German (15) and Italian (16) patient cohorts, although other studies do not support such a correlation $(17,18)$. An increased frequency of the $\mathrm{C} 77 \mathrm{G}$ variant allele has been demonstrated in HIV-1 infected individuals (19), in systemic sclerosis (20) and in autoimmune hepatitis (21). These observations suggest that abnormal CD45 
splicing is associated with altered immunologic function, autoimmunity and viral infections. Sentence deleted.

Two patients with a similar defect in CD45 splicing associated with familial hemophagocytic lymphohistiocytosis (22, 23) have been previously described. Hemophagocytic lymphohistiocytosis (HLH) comprises a heterogenous group of disorders characterized by dysregulated activation of $\mathrm{T}$ lymphocytes and macrophages (24-26). Although some patients with HLH harbor perforin mutations (HLH type 2), others show link to a locus on chromosome 9 , while the cause of the remaining cases is not known (27-29). Langerhans cell histiocytosis (LCH) is another rare disorder characterized by the dysregulated proliferation of Langerhans cells and subsequent organ infiltration $(30,31)$. The pathogenesis of the disease is still unknown and the clinical picture is highly variable ranging from a benign course with spontaneous recovery to a very rapidly evolving process with a fatal outcome.

In this study we initially analyzed the two previously described patients with $\operatorname{HLH}(22,23)$ and unusual expression of CD45 isoforms, using flow cytometry and molecular typing. We further typed 21 other HLH patients for the C77G polymorphism. Subsequently we examined the frequency of the C77G polymorphism in a series of Italian patients affected by LCH compared with healthy Italian controls. Finally we analyzed the expression of various cell surface molecules of peripheral blood mononuclear cells from normal individuals with the $\mathrm{C} 77 \mathrm{G}$ variant. Our results show that individuals carrying the $\mathrm{C} 77 \mathrm{G}$ variant display phenotypic differences that might affect the migration and function of leukocytes. Further studies are warranted to determine whether CD45 splicing abnormalities play any role in the pathogenesis of histiocytosis.

\section{PATIENTS, MATERIALS AND METHODS}

Patients. Fresh blood was obtained from the previously described family W (23) and family G. (with two children with $\mathrm{HLH}$ ) from the Immunobiology Unit, Institute for Child Health, London, UK. Peripheral blood mononuclear cells (PBMC) were isolated by centrifugation on a Ficoll-Paque (Amersham Pharmacia Biotech, Buckinghamshire, UK) density gradient and genomic DNA was extracted by standard procedures (32). Genomic DNA samples from family R (22) together with genomic DNA samples from 19 unrelated Italian HLH patients ( 9 of which contained PRF1 mutations as previously described (33)), were provided by MA.

The characteristics of the HLH patients $(22,23)$ with $\mathrm{C} 77 \mathrm{G}$ are as follows:

The patient R. was a first child of consanguineous Belgian Caucasian parents (22). The patient presented at the age of 2 mo with fever, hepatosplenomegaly, neutropenia, thrombocytopenia, hypofibrinogenemia, and hypertriglyceridemia. He responded to initial treatment with etoposide and underwent bone marrow transplantation from his haploidentical half-sibling and remained asymptomatic over 8 y later.

Patient W. was the third child of healthy unrelated British Caucasian parents (23). He presented aged 3 mo with fever, diarrhea, pallor, increasing irritability and marked cervical lymphoadenopathy and hepatosplenomegaly. Laboratory in- vestigations revealed pancytopenia, coagulopathy and hypertriglyceridemia. The diagnosis of HLH was made from the bone marrow aspirate, which showed hemophagocytosis. There was a good response to initial treatment with dexamethasone and etoposide and he underwent allogeneic bone marrow transplantation from his HLA identical brother.

Sixty-two LCH patients were analyzed, and forty-one were diagnosed with LCH when younger than $18 \mathrm{y}$. Patients' age at time of diagnosis ranged from 5 mo to $17 \mathrm{y}$ with a mean age of $4.73 \mathrm{y}$ and the female to male ration was 1:1.62. The diagnosis of LCH was biopsy proven, according to current diagnostic criteria established by the Histiocyte Society. The control population consisted of 199 unrelated Italians samples, including medical students, blood donors and university staff, representative of the whole country with a male to female ratio of $1: 1.15$ (30\% being under the age of 18).

The main features of the three patients with $\mathrm{LCH}$ and the $\mathrm{C} 77 \mathrm{G}$ mutation are as follows.

\section{CASE 1.}

S.F., male. At the age of $3.5 \mathrm{y}$ he developed a cranial swelling. Skull $\mathrm{x}$-ray and CT scan revealed an isolated osteolytic region. Surgical biopsy confirmed the diagnosis of CD1apositive LCH. Complete diagnostic work up ruled out any additional location of disease. One year later the lesion healed without any additional treatment and, after $1 \mathrm{y}$, the child remains asymptomatic.

\section{CASE 2.}

B.S., female. At the age of 5.4 y a skull x-ray performed because of minor trauma revealed an osteolytic region. Surgical biopsy confirmed the diagnosis of CDla-positive LCH. Complete diagnostic work up ruled any additional location of disease. One year later the lesion healed without any additional treatment and, after $1 \mathrm{y}$, the child remains asymptomatic.

\section{CASE 3.}

M. F., male. At the age of $17 \mathrm{y}$ he developed polyuria and polydipsia, was diagnosed as affected with diabetes insipidus. Clinical evaluation showed osteolytic lesions and moderate liver dysfunction. Histologic diagnosis of bone lesions was confirmed as $\mathrm{LCH}$ by demonstrating $\mathrm{CD} 1 \mathrm{a}+$ cells. A thorough diagnostic work-up showed multisystem LCH with multifocal bone lesions and endocrine defects (diabetes insipidus and GH deficiency with thick pituitary stalk). During the following years he showed recurrent bouts of bony reactivation; since nonsteroidal anti-inflammatory drug therapy was unsuccessful, he underwent treatment with vinblastin and steroids according to the LCH-II study protocol. At the time of writing he is asymptomatic with sub-clinical liver and lung involvement.

Buffy coats bags were obtained from the National Blood Transfusion Service (London, UK), genotyped for the presence of $\mathrm{C} 77 \mathrm{G}$ variant and used for flow cytometric analysis as described below.

The patients gave informed consent for the study and approval was obtained from the ethical review board of the Edward Jenner Institute for Vaccine Research.

Genotyping for CD45 Exon A (C77G) Mutation. Genomic DNA was amplified by PCR using forward (5'-GACTACAG- 
CAAAGATGCCCAGTG-3') and reverse (5'-GGGATACTTGGGTGGAAGTA-3') primers as previously described (34). The PCR and digestion products were analyzed on VisiGel Separation Matrix (Stratagene, La Jolla, CA, U.S.A.).

Flow Cytometric Analysis. PBMC were stimulated for $12 \mathrm{~d}$ with $1 \mu \mathrm{g} / \mathrm{mL}$ of PHA-P (Sigma Chemical Co., St. Louis, MO, U.S.A.) adding IL-2 on day 10 . Flow cytometric analysis of CD45 variant splicing was performed as previously described (34). Briefly, $2 \times 10^{5}$ PBMC were stained with either APCconjugated CD4 (S3.3, Caltag, Siulverstone, UK) or CD8-APC (clone RPA/T8, Pharmingen, San Diego, CA, U.S.A.) along with FITC-conjugated CD45RA (clone HI10, Pharmingen) and PE-conjugated CD45R0 (clone UCHL1, Pharmingen) mAbs in a single step at $4^{\circ} \mathrm{C}$ for 20 min and washed with PBS, containing $0.2 \% \mathrm{BSA}$. The following reagents and antibodies were also used to stain cell suspensions: CD11a-FITC (G43-25B), CD28-FITC (CD28.2), CD44-FITC (G44-26), CD62L-FITC (Dreg56), CD95-FITC (DX2), CCR7 (2H4) were all from PharMingen, CD62L-FITC (LAM1-116) (Ancell, Bayport, U.S.A.), CD69-FITC (CH14) (Caltag, Silverstone, UK), HLADR-FITC (TU36) (Caltag), CD25-FITC (ACT-1) (Dako), CD4-FITC (Dako), CD27-FITC (LT27) (Serotec, Kidlington, UK). Isotype matched mAbs were used as controls. 10,000 or 50,000 events per sample were collected on a FACSCalibur (Becton Dickinson, Mountain View, CA, U.S.A.) and analyzed using WinMDI software.

Statistical Analysis. The Fisher exact test was used to analyze the association of $\mathrm{C} 77 \mathrm{G}$ polymorphism and $\mathrm{LCH}$ or HLH. For comparison of phenotypic analyses between cell subsets in $\mathrm{C} 77 \mathrm{G}$ and control individuals, the $t$ test, assuming equal variance, was used.

\section{RESULTS}

The C77G variant is the cause of CD45 abnormal splicing in two families with $\mathrm{HLH}$. We obtained material from two patients with HLH, previously described as exhibiting CD45 abnormal splicing, as characterized by the lack of the single CD45R0 + T cell population $(22,23)$. Subsequently the C77G mutation in exon A of CD45 has been shown to be a common cause for abnormal CD45 splicing in T lymphocytes $(10,34)$. We therefore re-examined these patients and members of their families to establish the cause for abnormal CD45 splicing.

In the first family reported, the patient $\mathrm{R}$. was a first child of consanguineous Belgian Caucasian parents (22). Genotyping for the $\mathrm{C} 77 \mathrm{G}$ polymorphism revealed that the patient and his mother are heterozygotes while his father and grandmother (also the father's sister) carried wild type CD45 (data not shown). Material from two half-siblings, who died from histiocytic disorders, was not available to us. No perforin mutations were detected in this family as analyzed by sequencing of exons 2 and 3 .

In the second family six members were analyzed (23). Patient W. was the third child of healthy unrelated British Caucasian parents. Using PCR and $M s p \mathrm{I}$ restriction analysis we found that patient $\mathrm{W}$. his mother and two siblings were heterozygous for the mutant $\mathrm{C} 77 \mathrm{G}$ allele, while the father and the oldest brother had wild type CD45 (Fig. 1A). These results
A.
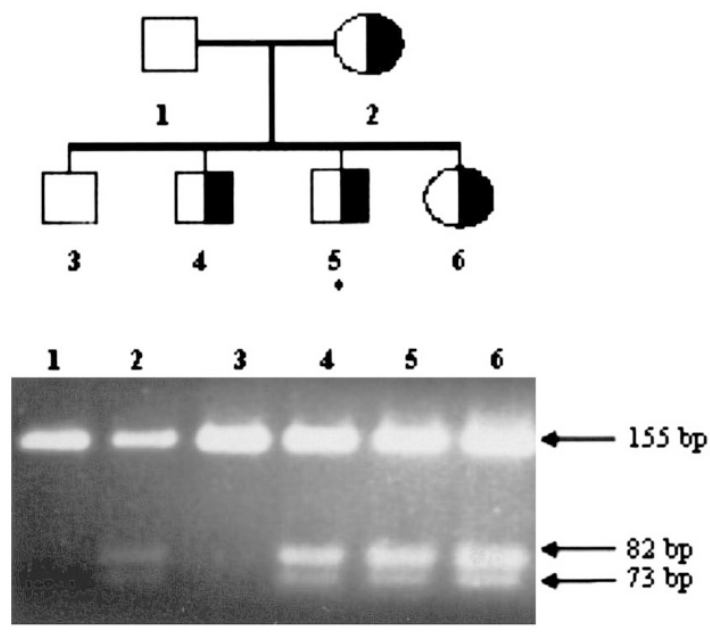

B

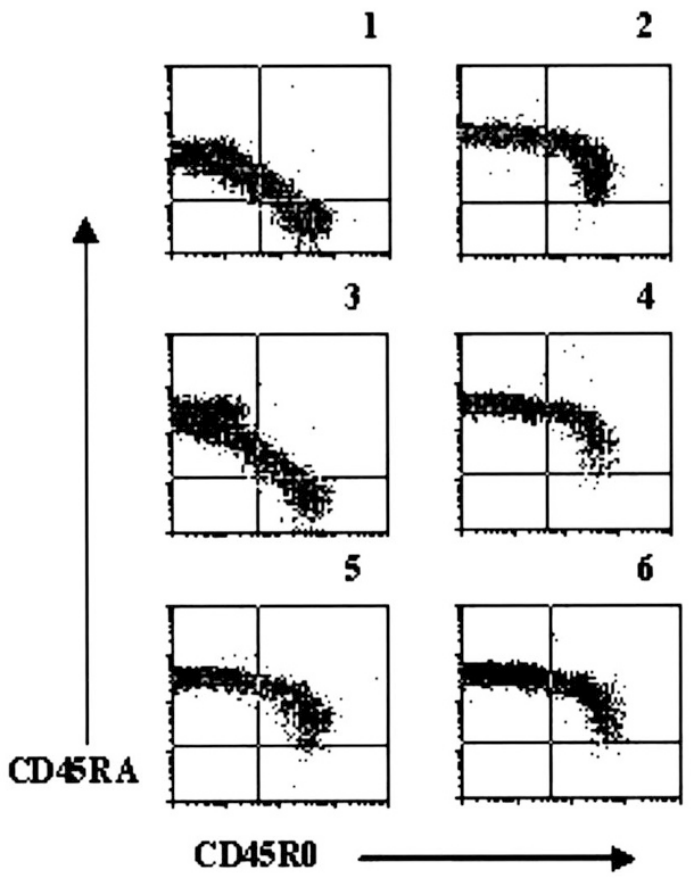

Figure 1. CD45 genotype and phenotype of family W. Family tree indicating the CD45 genotype and phenotype in each member of family $\mathrm{W}$. The patient with HLH (5) is indicated by an asterisk. $(A)$ Identification of the CD45 exon A $(C 77 G)$ mutation in family $\mathrm{W}$. The $\mathrm{C} 77 \mathrm{G}$ transversion introduces a new restriction site for $M s p I$, which cleaves the mutant PCR product into two fragments of 72 and 83 bp (lanes 2, 4, 5, and 6). The presence of an undigested band of $155 \mathrm{bp}$ indicates the presence of the wild type allele in the father and older brother (lanes 1 and 3). (B) Expression of CD45 isoforms in human peripheral T cells. PBMC were stained with isoform specific CD45RA-FITC and CD45R0-PE together with CD4-APC mAbs. Analysis was performed on gated $\mathrm{CD} 4{ }^{+}$cells. The normal pattern of $\mathrm{CD} 45$ isoform expression is characterized by the presence of single $\mathrm{CD} 45 \mathrm{RA}^{+}$and single $\mathrm{CD} 45 \mathrm{R} 0^{+}$cells. Abnormal CD45 expression was seen in the patient (5), his mother (2) and two siblings (4 and 6). The father (1) and brother (3) have normal CD45 pattern of expression.

were confirmed by flow cytometric analysis on PBMC from family W. (Fig. 1B). All of the family members genotyped as 
having the $\mathrm{C} 77 \mathrm{G}$ mutation exhibit phenotypically abnormal CD45 splicing. Members of this family exhibited a novel missense mutation in the $\mathrm{Ca}^{++}$binding domain of perforin, which interestingly co segregated with the $\mathrm{C} 77 \mathrm{G}$ mutation (35).

Taken together, these results show that the CD45 exon A $(\mathrm{C} 77 \mathrm{G})$ mutation is the cause for the CD45 abnormal splicing in these two previously described HLH patients.

Analysis of C77G mutation in $21 \mathrm{HLH}$ patients. Since two families with HLH were identified with abnormal CD45 splicing and the $\mathrm{C} 77 \mathrm{G}$ mutation we next investigated the pattern of CD45 expression in other HLH patients. Using PCR and MspI restriction analysis we genotyped 21 patients with HLH (including the two affected siblings from family G.) for the presence of the $\mathrm{C} 77 \mathrm{G}$ mutation. Nine of these cases had previously identified perforin mutations (HLH type 2) (33), while the remaining twelve show an HLH 1 phenotype and the presence of known deleterious PRF1 mutations has been excluded by sequencing exons 2 and 3 . We did not find the mutant $\mathrm{C} 77 \mathrm{G}$ allele in any of these patients.

Analysis of C $77 G$ variant in $\mathbf{L C H}$ patients. $\mathrm{LCH}$ is another disorder classified as a histiocytosis and characterized by lesions infiltrated by cells of the dendritic cell lineage. Therefore we investigated the pattern of CD45 expression in a cohort of Italian patients with LCH. Using PCR and MspI digestion we identified 3 individuals with the $\mathrm{C} 77 \mathrm{G}$ mutation out of $41 \mathrm{LCH}$ infantile patients (frequency of $7.3 \%$ ), while no mutation was found in patients older than 18 . The $\mathrm{C} 77 \mathrm{G}$ mutation was observed in 1 out of the 199 controls (frequency $0.5 \%$ ). Using a two tailed Fisher's exact test to test for the association between $\mathrm{C} 77 \mathrm{G}$ mutation and $\mathrm{LCH}$ a statistically significant association was demonstrated $(p=0.043$, on the overall frequency in $\mathrm{LCH} 4.8 \%$ versus $0.5 \%$ in control).

Phenotypic analysis of PBMC of individuals with the C77G variant: CD45 isoform expression. We next examined whether the abnormal pattern of CD45 isoform expression affects other aspects of leukocyte phenotype. Cryopreserved PBMCs from healthy individuals known to carry the $\mathrm{C} 77 \mathrm{G}$ mutation and cryopreserved normal control cells were analyzed by flow cytometry. No apparent differences in the proportion of CD3, CD4, CD8, CD14, and CD19 cells were observed between the individuals with the $\mathrm{C} 77 \mathrm{G}$ variant and wild type CD45 (data not shown). All of the C77G samples showed the previously described typical pattern of CD45 isoform expression on both CD4 and CD8 cells (Fig. 2A). Even after $12 \mathrm{~d}$ stimulation with PHA and IL-2 stimulation, neither CD4 nor $\mathrm{CD} 8$ cells of $\mathrm{C} 77 \mathrm{G}$ individuals were able to switch to expression of only the CD45R0 isoform (data not shown). However, it is noteworthy that the CD8 cells of individuals with the C77G mutation have more CD45RA single positive cells (mean 75\%) compared with normal individuals (mean 58\%) ( $p$ $=0.001$ for $6 \mathrm{C} 77 \mathrm{G}$ carriers and 6 controls) (Fig. $2 A$ and $B$ ). In contrast the proportions of CD45RA versus $\mathrm{CD} 45 \mathrm{R} 0$ or CD45RA/R0 double positive cells are similar among CD4 cells from $\mathrm{C} 77 \mathrm{G}$ and control samples.

The phenotype of CD8 T cells in individuals with the C77G variant. Because of the strikingly altered proportions of CD45RA positive versus CD45R0 or CD45RA/R0 double
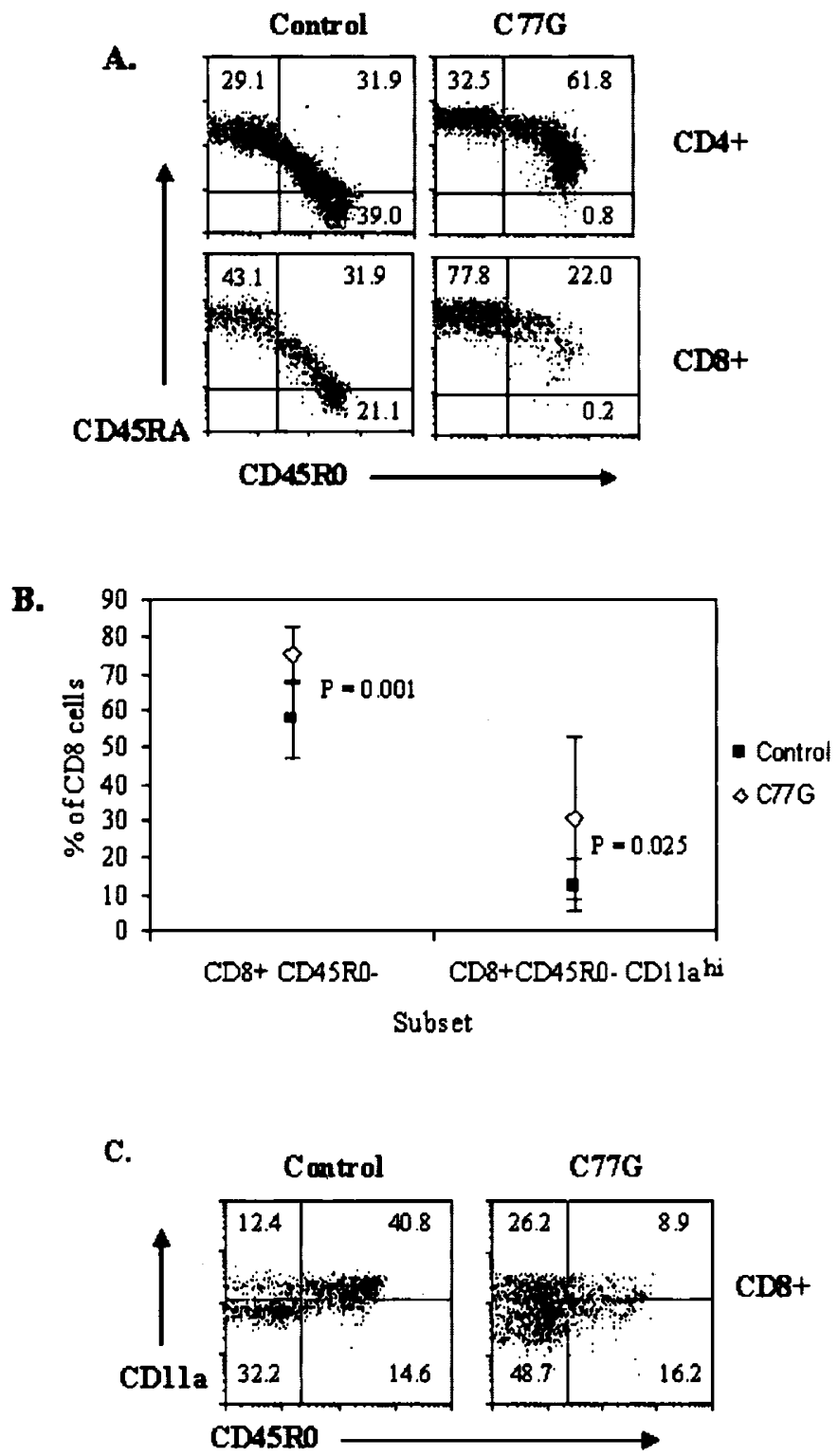

Figure 2. Expression of $\mathrm{CD} 45$ isoforms and $\mathrm{CD} 11 \mathrm{a}$ on $\mathrm{T}$ cells from $\mathrm{C} 77 \mathrm{G}$ and control individuals. (A) PBMC were stained with isoform specific CD45R0-PE and CD45RA-FITC antibodies and CD4 and CD8 gated cells were analyzed. Abnormal CD45 splicing can be identified by the absence of the CD45RA-negative population. Data are representative of analyses of six C77G individuals and six controls. $(B)$ The proportions of CD8 T cells from $\mathrm{C} 77 \mathrm{G}$ and normal individuals that are CD45R0 - or are CD11 $\mathrm{a}^{\text {hi }}$. Means and standard deviations of data expressed as the percentage of CD8 T cells from six C77G and six normal individuals are shown. (C) Expression of CD11a on CD8 $\mathrm{T}$ cells from $\mathrm{C} 77 \mathrm{G}$ and normal individuals. Data are representative of analyses of six $\mathrm{C} 77 \mathrm{G}$ individuals and six controls.

positive cells among CD8 cells from C77G and control individuals we next examined the expression of various cell surface markers associated with lymphocyte activation, analyzing them in the CD45R0+ and CD45R0 - subsets. No statistically significant differences were observed in the expression of the adhesion molecule CD44, the costimulatory molecule CD28, cytokine and chemokine receptors CD25 and CCR7, and the activation markers CD69 and HLA-DR (data not shown).

However, an increased frequency of CD8 cells expressing high levels of the adhesion molecule CD11a (CD11ahi ) was 
detected in the (enlarged) CD45R0 - subset $(p=0.025)$ (Fig. $2 B$ and $C$ ). In the CD45R0+ subset the expression of CD27, CD62L and CD95 was significantly decreased in C77G individuals compared with controls (Fig. $3 A$ and $B$ ). The differences in CD62L expression were confirmed with a different CD62L antibody (clone LAM1-116, data not shown), suggesting that the observed variances were not due to differential glycosylation of surface molecules in $\mathrm{C} 77 \mathrm{G}$ and control cells.

\section{DISCUSSION}

It is becoming clear that many if not all diseases are the result of a complex interaction between individuals and their environment involving multiple host genes. The complexity of this interaction is illustrated by individuals with abnormal CD45 splicing, who have persistent expression of the high molecular weight CD45RA isoforms (9). In this study we analyzed the association between abnormal CD45 splicing and HLH and LCH syndromes. HLH and LCH are classified as histiocytoses, a group of rare diseases, characterized by accumulation of pleomorphic infiltrates of leukocytes into many tissues. A hallmark of the infiltrates is the presence of histiocytic cells such as macrophages and dendritic cells. The etiology of these disorders remains obscure although some cases of

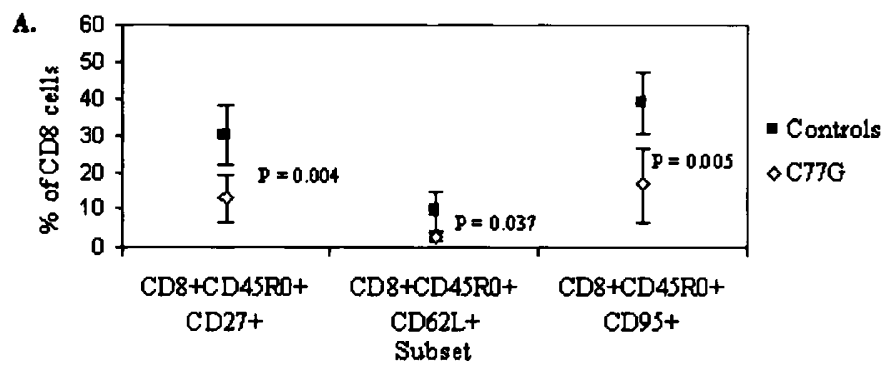

B.

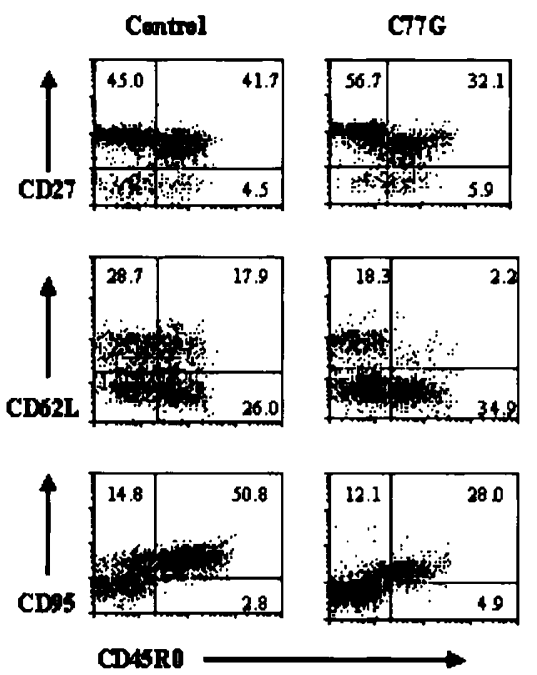

Figure 3. CD62L, CD27 and CD95 expression on CD8 + CD45R0+ cells. (A) Proportions of CD8 T cells in the CD45R0 subset that express CD27, CD62L, and CD95. Means and standard deviations of data from six C77G and six control individuals are shown. (B) Flow cytometric dot plots show PBMC samples from $\mathrm{C} 77 \mathrm{G}$ and normal individuals stained with $\mathrm{CD} 27, \mathrm{CD} 62 \mathrm{~L}$ and CD95 and gated on CD8 T cells. Examples are representative of similar analyses of six $\mathrm{C} 77 \mathrm{G}$ and control individuals.
HLH are associated with perforin gene mutations $(28,29,36$, 37 ) and there is evidence that LCH is a clonal proliferation. Environmental triggers such as viral infections and smoking have also been invoked in the case of $\operatorname{LCH}(31,38,39)$.

We studied two patients with HLH previously described as exhibiting abnormal CD45 splicing $(22,23)$ and found that the $\mathrm{C} 77 \mathrm{G}$ polymorphism is the cause for the observed variant splicing (35). Sentence deleted. We have examined the association between $\mathrm{C} 77 \mathrm{G}$ mutation and HLH in an additional 21 DNA samples and none of these were $\mathrm{C} 77 \mathrm{G}$ positive. This is, however, a very small group of varied origin (UK, Belgium, Italy) and it is therefore impossible to draw statistically significant conclusions although taken together these results show a frequency of 1:10 in HLH type 2 (with identified PRF1 mutations), or 2:23 for HLH overall (frequency $8.6 \%$ ). Published frequencies for normal individuals vary between $0 \%$ and $3.6 \%$ in different parts of Europe and North America (see below) (40).

We also investigated the distribution of the $\mathrm{C} 77 \mathrm{G}$ variant in a group of LCH patients as part of a larger study aiming to identify the genetic factors involved in the pathogenesis of this disorder. Here we show a statistically significant association of the $\mathrm{C} 77 \mathrm{G}$ mutation and LCH $(p=0.043)$. We identified 3 individuals with the $\mathrm{C} 77 \mathrm{G}$ variant out of $62 \mathrm{LCH}$ patients (frequency 4.8\%) compared with one out of 199 healthy controls (frequency $0.5 \%$ ). The association of $\mathrm{C} 77 \mathrm{G}$ and $\mathrm{LCH}$ does not result in any distinctive clinical manifestation of $\mathrm{LCH}$ as the age of onset of these patients is well within the control range and they include examples of both the most common clinical pattern of single system bone LCH, as well as multisystem disease. Their clinical course was not unusual.

The frequency of the $\mathrm{C} 77 \mathrm{G}$ variant in different populations has not been extensively studied. Here we show a frequency of $0.5 \%$ individuals with $\mathrm{C} 77 \mathrm{G}$ polymorphism among 199 healthy donors from Italy, which is in agreement with another study (16). However another more recent study found frequencies of 2.3 and $1.3 \%$ in Northern and Southern Italy respectively (40). These appear slightly lower frequencies compared with 3.6\% in North America, 2.8\% in Sweden, and 1.76\% in the UK. However a study in Germany found less then $1 \%$ C77G positive individuals and none were found among 527 African samples (41). One might speculate that the distribution of the $\mathrm{C} 77 \mathrm{G}$ variant throughout Europe decreases from North to South, but clearly further studies are required to establish whether these apparent differences are associated with ethnic variations or the health status of the populations tested. More extensive studies need to be performed to establish the frequency of abnormal CD45 splicing and the $\mathrm{C} 77 \mathrm{G}$ variant allele in HLH and LCH.

Thorough phenotypic and functional analysis has not been performed on $\mathrm{C} 77 \mathrm{G}$ heterozygous individuals so far. Our results indicate that the normal carriers of the $\mathrm{C} 77 \mathrm{G}$ mutation have normal proportions of $\mathrm{T}$ cells, $\mathrm{B}$ cells and monocytes in peripheral blood. Monocytes, which normally express the low molecular weight CD45 R0 isoform, express higher amount of CD45RA in C77G carriers compared with normal individuals (data not shown). Further studies of the phenotype of these 
cells are required in relation to the pathogenesis of these two diseases.

However, there were significant differences in the expression of various phenotypic markers associated with activation and differentiation of $\mathrm{T}$ cells namely - the adhesion molecules CD11a and CD62L, the co-stimulatory molecule CD27 and the activation antigen CD95. There was also a striking increase in the proportion of CD45RA single positive CD8 $\mathrm{T}$ cells in C77G samples; $75 \%$ versus $58 \%$ in controls. The expression of CD11a suggests that these cells may be primed CD45RA "revertants" $(42,43)$. Decreased expression of CD62L and $\mathrm{CD} 27$ in individuals with $\mathrm{C} 77 \mathrm{G}$ indicates that these individuals have an increased proportion of CD8 T cells with an activated/ effector phenotype capable of migrating into no-lymphoid tissues. This would be consistent with the increased infiltration of lymphocytes found in HLH and LCH.

While there has been considerable success in identifying the genes implicated in Mendelian disorders, the identification of susceptibility genes underlying multifactorial diseases has progressed more slowly. This study illustrates the difficulties involved, particularly in the case of rare diseases such as HLH and LCH. Here we have shown that the frequency of the $\mathrm{C} 77 \mathrm{G}$ allele is increased in a cohort of LCH patients compared with controls, we have no evidence that there is an increased frequency in HLH. Separately we have shown evidence for the presence of a population of activated $\mathrm{T}$ cell effectors in normal individuals with the $\mathrm{C} 77 \mathrm{G}$ allele. We have not established a causal role for $\mathrm{C} 77 \mathrm{G}$ in $\mathrm{HLH}$ or $\mathrm{LCH}$, but suggest that this merits further investigation.

Acknowledgments. We thank the patient's families, clinicians, and nurses for help with patient samples.

\section{REFERENCES}

1. Penninger JM, Irie-Sasaki J, Sasaki T, Oliveira-Dos-Santos AJ 2001 CD45: new jobs for an old acquaintance. Nat Immunol 2:389-396

2. Kishihara K, Penninger J, Wallace VA, Kundig TM, Kawai K, Wakeham A, Timms E, Pfeffer K, Ohashi PS, Thomas ML 1993 Normal B lymphocyte development but impaired $\mathrm{T}$ cell maturation in CD45-exon6 protein tyrosine phosphatase-deficient mice. Cell 74:143-156

3. Byth KF, Conroy LA, Howlett S, Smith AJ, May J, Alexander DR, Holmes N 1996 CD45-null transgenic mice reveal a positive regulatory role for CD45 in early thymocyte development, in the selection of CD4+CD8+ thymocytes, and B cell maturation. J Exp Med 183:1707-1718

4. Kung C, Pingel JT, Heikinheimo M, Klemola T, Varkila K, Yoo LI, Vuopala K, Poyhonen M, Uhari M, Rogers M, Speck SH, Chatila T, Thomas ML 2000 Mutations in the tyrosine phosphatase CD45 gene in a child with severe combined immunodeficiency disease. Nat Med 6:343-345

5. Tchilian EZ, Wallace DL, Wells RS, Flower DR, Morgan G, Beverley PC 2001 A deletion in the gene encoding the CD45 antigen in a patient with SCID. J Immunol 166:1308-1313

6. Streuli M, Hall LR, Saga Y, Schlossman SF, Saito H 1987 Differential usage of three exons generates at least five different mRNAs encoding human leukocyte common antigens. J Exp Med 166:1548-1566

7. Saga Y, Tung JS, Shen FW, Boyse EA 1986 Sequences of Ly-5 cDNA: isoformrelated diversity of Ly-5 mRNA. Proc Natl Acad Sci USA 83:6940-6944

8. Akbar AN, Terry L, Timms A, Beverley PC, Janossy G 1988 Loss of CD45R and gain of UCHL1 reactivity is a feature of primed T cells. J Immunol 140:2171-2178

9. Schwinzer R, Wonigeit K 1990 Genetically determined lack of CD45R- T cells in healthy individuals. Evidence for a regulatory polymorphism of CD45R antigen expression. J Exp Med 171:1803-1808

10. Thude H, Hundrieser J, Wonigeit K, Schwinzer R 1995 A point mutation in the human CD45 gene associated with defective splicing of exon A. Eur J Immunol 25:2101-2106

11. Zilch CF, Walker A, Timon M, Goff LK, Wallace DL, Beverley PC 1998 A point mutation within CD45 exon A is the cause of variant CD45RA splicing in humans. Eur J Immunol 28:22-29
12. Lynch KW, Weiss A 2001 A CD45 polymorphism associated with multiple sclerosis disrupts an exonic splicing silencer. J Biol Chem 276:24341-24347

13. Jacobsen M, Hoffmann S, Cepok S, Stei S, Ziegler A, Sommer N, Hemmer B 2002 A novel mutation in PTPRC interferes with splicing and alters the structure of the human CD45 molecule. Immunogenetics 54:158-163

14. Stanton T, Boxall S, Hirai K, Dawes R, Tonks S, Yasui T, Kanaoka Y, Yuldasheva N, Ishiko O, Bodmer W, Beverley PC, Tchilian EZ 2003 A high-frequency polymorphism in exon 6 of the CD45 tyrosine phosphatase gene (PTPRC) resulting in altered isoform expression. Proc Natl Acad Sci USA 100:5997-6002

15. Jacobsen M, Schweer D, Ziegler A, Gaber R, Schock S, Schwinzer R, Wonigeit K, Lindert RB, Kantarci O, Schaefer-Klein J, Schipper HI, Oertel WH, Heidenreich F, Weinshenker BG, Sommer N, Hemmer B 2000 A point mutation in PTPRC is associated with the development of multiple sclerosis. Nat Genet 26:495-499

16. Ballerini C, Rosati E, Salvetti M, Ristori G, Cannoni S, Biagioli T, Massacesi L, Sorbi S, Vergelli M 2002 Protein tyrosine phosphatase receptor-type C exon 4 gene mutation distribution in an Italian multiple sclerosis population. Neurosci Lett 328:325-327

17. Vorechovsky I, Kralovicova J, Tchilian E, Masterman T, Zhang Z, Ferry B, Misbah S, Chapel H, Webster D, Hellgren D, Anvret M, Hillert J, Hammarstrom L, Beverley PC 2001 Does $77 \mathrm{C} \rightarrow \mathrm{G}$ in PTPRC modify autoimmune disorders linked to the major histocompatibility locus? Nat Genet 29:22-23

18. Barcellos LF, Caillier S, Dragone L, Elder M, Vittinghoff E, Bucher P, Lincoln RR, Pericak-Vance M, Haines JL, Weiss A, Hauser SL, Oksenberg JR 2001 PTPRC (CD45) is not associated with the development of multiple sclerosis in U.S. patients. Nat Genet 29:23-24

19. Tchilian EZ, Wallace DL, Dawes R, Imami N, Burton C, Gotch F, Beverley PC 2001 A point mutation in CD45 may be associated with HIV-1 infection. AIDS 15:18921894

20. Schwinzer R, Witte T, Hundrieser J, Ehlers S, Momot T, Hunzelmann N, Krieg T, Schmidt RE, Wonigeit K 2003 Enhanced frequency of a PTPRC (CD45) exon A mutation $(77 \mathrm{C} \rightarrow \mathrm{G})$ in systemic sclerosis. Genes Immun 4:168-169

21. Vogel A, Strassburg CP, Manns MP 200377 C/G mutation in the tyrosine phosphatase CD45 gene and autoimmune hepatitis: evidence for a genetic link. Genes Immun 4:79-81

22. Bujan W, Schandene L, Ferster A, De Valck C, Goldman M, Sariban E 1993 Abnormal T-cell phenotype in familial erythrophagocytic lymphohistiocytosis. Lancet 342:1296

23. Wagner R, Morgan G, Strobel S 1995 A prospective study of CD45 isoform expression in haemophagocytic lymphohistiocytosis; an abnormal inherited immunophenotype in one family. Clin Exp Immunol 99:216-220

24. Janka GE 1983 Familial hemophagocytic lymphohistiocytosis. Eur J Pediatr 140:221-230

25. Dreyer ZE, Dowell BL, Chen H, Hawkins E, McClain KL 1991 Infection-associated hemophagocytic syndrome. Evidence for Epstein-Barr virus gene expression. Am J Pediatr Hematol Oncol 13:476-481

26. Dufourcq-Lagelouse R, Jabado N, Le Deist F, Stephan JL, Souillet G, Bruin M, Vilmer E, Schneider M, Janka G, Fischer A, de Basile G 1999 Linkage of familial hemophagocytic lymphohistiocytosis to 10q21-22 and evidence for heterogeneity. Am J Hum Genet 64:172-179

27. Ohadi M, Lalloz MR, Sham P, Zhao J, Dearlove AM, Shiach C, Kinsey S, Rhodes M, Layton DM 1999 Localization of a gene for familial hemophagocytic lymphohistiocytosis at chromosome 9q21.3-22 by homozygosity mapping. Am J Hum Genet 64:165-171

28. Stepp SE, Dufourcq-Lagelouse R, Le Deist F, Bhawan S, Certain S, Mathew PA, Henter JI, Bennett M, Fischer A, de Saint Basile G, Kumar V 1999 Perforin gene defects in familial hemophagocytic lymphohistiocytosis. Science 286:1957-1959

29. Ericson G, Fadeel B, Nilsson-Ardnor S, Soderhall C, Samuelsson A, Janka G, Schneider M, Gurgey A, Yalman N, Revesz T, Egeler R, Jahnukainen K, StormMathiesen I, Haraldsson A, Poole J, de Saint Basile G, Nordenskjold M, Henter J 2001 Spectrum of perforin gene mutations in familial hemophagocytic lymphohistiocytosis. Am J Hum Genet 68:590-597

30. Arico M, Egeler RM 1998 Clinical aspects of Langerhans cell histiocytosis. Hematol Oncol Clin North Am 12:247-258

31. Bhatia S, Nesbit ME Jr, Egeler RM, Buckley JD, Mertens A, Robison LL 1997 Epidemiologic study of Langerhans cell histiocytosis in children. J Pediatr 130:774784

32. Sambrook J, Fritsch EF, Maniatis T 1989 In: Molecular Cloning: A Laboratory Manual. Cold Spring Harbour Laboratory Press, New York, pp 9.16-9.19

33. Clementi R, zur Stadt U, Savoldi G, Varoitto S, Conter V, De Fusco C, Notarangelo LD, Schneider M, Klersy C, Janka G, Danesino C, Arico M 2001 Six novel mutations in the PRF1 gene in children with haemophagocytic lymphohistiocytosis. J Med Genet 38:643-646

34. Tchilian EZ, Wallace DL, Imami N, Liao HX, Burton C, Gotch F, Martinson J, Haynes BF, Beverley PC 2001 The exon A $(\mathrm{C} 77 \mathrm{G})$ mutation is a common cause of abnormal CD45 splicing in humans. J Immunol 166:6144-6148

35. McCormick J, Flower DR, Strobel S, Wallace DL, Beverley PC, Tchilian EZ 2003 Novel perforin mutation in a patient with hemophagocytic lymphohistiocytosis and CD45 abnormal splicing. Am J Med Genet 117A:255-260

36. Arico M, Allen M, Brusa S, Clementi R, Pende D, Maccario R, Moretta L, Danesino C 2002 Haemophagocytic lymphohistiocytosis: proposal of a diagnostic algorithm based on perforin expression. Br J Haematol 119:180-188

37. Arico M, Danesino C, Pende D, Moretta L 2001 Pathogenesis of haemophagocytic lymphohistiocytosis. Br J Haematol 114:761-769

38. Arico M, Danesino C 2001 Langerhans' cell histiocytosis: is there a role for genetics? Haematologica 86:1009-1014 
39. Willman CL, Busque L, Griffith BB, Favara BE, McClain KL, Duncan MH, Gilliland DG 1994 Langerhans'-cell histiocytosis (histiocytosis X)-a clonal proliferative disease. N Engl J Med 331:154-160

40. Gomez-Lira M, Liguori M, Magnani C, Bonamini D, Salviati A, Leone M, Andreoli V, Trojano M, Valentino P, Savettieri G, Quattrone A, Pignatti PF, MomiglianoRichiardi P, Giordano M 2003 CD45 and multiple sclerosis: the exon 4 C77G polymorphism (additional studies and meta-analysis) and new markers. J Neuroimmunol 140:216-221

41. Tchilian EZ, Dawes R, Ramaley PA, Whitworth JA, Yuldasheva N, Wells S, Watera C, French N, Gilks CF, Kunachiwa W, Ruzibakiev R, Leetrakool N, Carrington CF,
Ramdath D, Gotch F, Stephens HA, Hill AV, Beverley PL 2002 A CD45 polymorphism associated with abnormal splicing is absent in African populations. Immunogenetics 53:980-983

42. Maini MK, Gudgeon N, Wedderburn LR, Rickinson AB, Beverley PC 2000 Clonal expansions in acute EBV infection are detectable in the CD8 and not the CD4 subset and persist with a variable CD45 phenotype. J Immunol 165:5729-5737

43. Faint JM, Annels NE, Curnow SJ, Shields P, Pilling D, Hislop AD, Wu L, Akbar AN, Buckley CD, Moss PA, Adams DH, Rickinson AB, Salmon M 2001 Memory T cells constitute a subset of the human CD8+CD45RA + pool with distinct phenotypic and migratory characteristics. J Immunol 167:212-220 